\title{
Influence of Chicken Manure Amendment on the Thermal Properties of Selected Benchmark Soils in Zambia
}

\author{
Mary Mwale Chishala, Elijah Phiri, Lydia M. Chabala \\ Department of Soil Science, School of Agricultural Sciences, University of Zambia, Lusaka, Zambia \\ Email: ephiri@unza.zm
}

How to cite this paper: Chishala, M.M., Phiri, E. and Chabala, L.M. (2019) Influence of Chicken Manure Amendment on the Thermal Properties of Selected Benchmark Soils in Zambia. Open Journal of Soil Science, 9, 35-46.

https://doi.org/10.4236/ojss.2019.92002

Received: December 15, 2018

Accepted: February 25, 2019

Published: February 28, 2019

Copyright (c) 2019 by author(s) and Scientific Research Publishing Inc. This work is licensed under the Creative Commons Attribution International License (CC BY 4.0).

http://creativecommons.org/licenses/by/4.0/

\begin{abstract}
Influence of Chicken Manure amendment on the thermal properties of selected Benchmark soils in Zambia was investigated in the laboratory under soil column experiments. Five benchmark soils were exerted to four chicken manure amendment rates of $0 \%$ (control), $2 \%, 4 \%$ and $6 \%$ on a weight basis. Soil temperature profiles were monitored in soil columns exerted to artificial heat source and generated data was used to compute the thermal properties of the soils. The effect of manure application on the soil thermal properties was strongly related to soil type and application rate. Significant differences $(p<0.05)$ were observed in volumetric heat capacity, thermal diffusivity and damping depth among the benchmark soils. The volumetric heat capacity varied from $3.87 \mathrm{MJ} \cdot \mathrm{m}^{-3} \cdot \mathrm{c}^{-1}$ (Mushemi series) to $8.62 \mathrm{MJ} \cdot \mathrm{m}^{-3} \cdot \mathrm{c}^{-1}$ (Makeni series) and attributed to differences in soil characteristics. Thermal diffusivity varied from $0.028 \mathrm{~m}^{2} \cdot \mathrm{s}^{-1}$ (Makeni series) to $0.069 \mathrm{~m}^{2} \cdot \mathrm{s}^{-1}$ (Mushemi series) a reverse trend to thermal conductivity. A similar trend was observed with damping depth however thermal conductivity was not significantly different among the benchmark soils. The studied soils showed significant differences $(\mathrm{p}<0.05)$ in their thermal properties with chicken manure amendment. Thermal conductivity $(\lambda)$, thermal diffusivity $\left(D_{h}\right)$ and damping depth $(d)$ decreased while volumetric heat capacity $(\mathrm{Cv})$ increased with increased chicken manure addition. The differences in these thermal properties were attributed to differences in soil properties. These results suggest that chicken manure application can be an important intervention in regulation of the thermal properties of the soil and consequently the thermal regime of the soil.
\end{abstract}

\section{Keywords}

Thermal Regime, Chicken Manure, Benchmark Soils, Climate Change, Temperature 


\section{Introduction}

Thermal properties of soils are important attributes to heat transfer in the soil through conduction, convection, and radiation [1] hence dictating the soil surface energy budget [2] [3], hydrologic processes [4], and greenhouse gas emissions [5]. These thermal properties dictate the retention and transmission of heat within and out of the soil and influence temperature and heat flux with time and depth [6]. Although soil temperature measurements are routine, in situ measurements of thermal properties of soil are rare. In agriculture, thermal properties play an important role to ensure optimal emergence and crop growth [7]. The measurement of thermal properties is also necessary for determining mass and energy exchange processes which take place in the soil-plant-atmosphere continuum. Therefore, investigating soil thermal properties helps evaluate optimum conditions for plant growth and development, and is important for controlling soil thermal moisture regime [8].

The use of chicken manure as an organic amendment improves soil quality. The need and utilization of chicken manure are attributed to its high content of nitrogen, phosphorus and potassium [9] and increased organic matter content [10], rarely mentioned in improved thermal properties. A benchmark soil is one of large extent within one or more major land resource areas (MLRA), one that holds a key position in the soil classification system, one for which there is a large amount of data, one that has special importance to one or more significant land uses, or one that is of significant ecological importance.

Benchmark soils are important in the soil classification and provide a good basis for understanding soil properties. These soils data presents a special significance to farming, engineering, forestry, urban development, wetland, and other uses [11]. Information about Benchmark soils can be extended to those soils that are closely related to classification and geography [12]. However, current investigation on soils shows there is limited research on the influence of chicken manure amendment on the thermal properties of selected benchmark soils in Zambia. Hence, this study aimed at assessing thermal properties (thermal conductivity, volumetric heat capacity, and thermal diffusivity) of selected benchmark soils and evaluating the influence of chicken manure amendment on the same thermal properties of selected benchmark soils.

\section{Materials and Methods}

\subsection{Site Description}

The Benchmark soils also referred to as soil series used in the study were collected $0-0.2 \mathrm{~m}$ soil depth from five (5) sites located in Agro-ecological region (AEZ) IIa of Zambia (Table 1, Figure 1). These soil types are well defined, characterized and representative of the main productive soils in Zambia [13].

\subsection{Preparation Soil and Chicken Manure Samples}

Composite soil samples were collected from five benchmark soil series while at 
Table 1. Classification and location of Benchmark soils used in the study.

\begin{tabular}{|c|c|c|}
\hline Soil Series & Soil Classification (USDA) & Location \\
\hline Chelston & Fine, Mixed, Isohyperthermic Typic Kandiustalf & Liempe Farm $\left(\mathrm{S} 15.394602^{\circ}, \mathrm{E} 28.467914^{\circ}\right)$ \\
\hline Nakambala & Fine-Loamy, Mixed, Hyperthermic Oxic Paleustalf & Mazabuka $\left(\mathrm{S} 15.815495^{\circ} \mathrm{E} 27.808566^{\circ}\right)$ \\
\hline Mushemi & Clayey, Kaolinitic, Isohyperthermic Ustic Kandiustalf & Kabwe (S14.395517 E28.497046 $)$ \\
\hline Makeni & Fine, Mixed, Isohyperthermic Udic Paleustoll & Lilayi Farm $\left(\mathrm{S} 15.515227^{\circ} \mathrm{E} 28.284358^{\circ}\right)$ \\
\hline Kashinka & Fine, Mixed, Isohyperthermic, Ustic Paleustalf & Mumbwa Road $\left(\mathrm{S} 15.423820^{\circ} \mathrm{E} 28.045540^{\circ}\right)$ \\
\hline
\end{tabular}

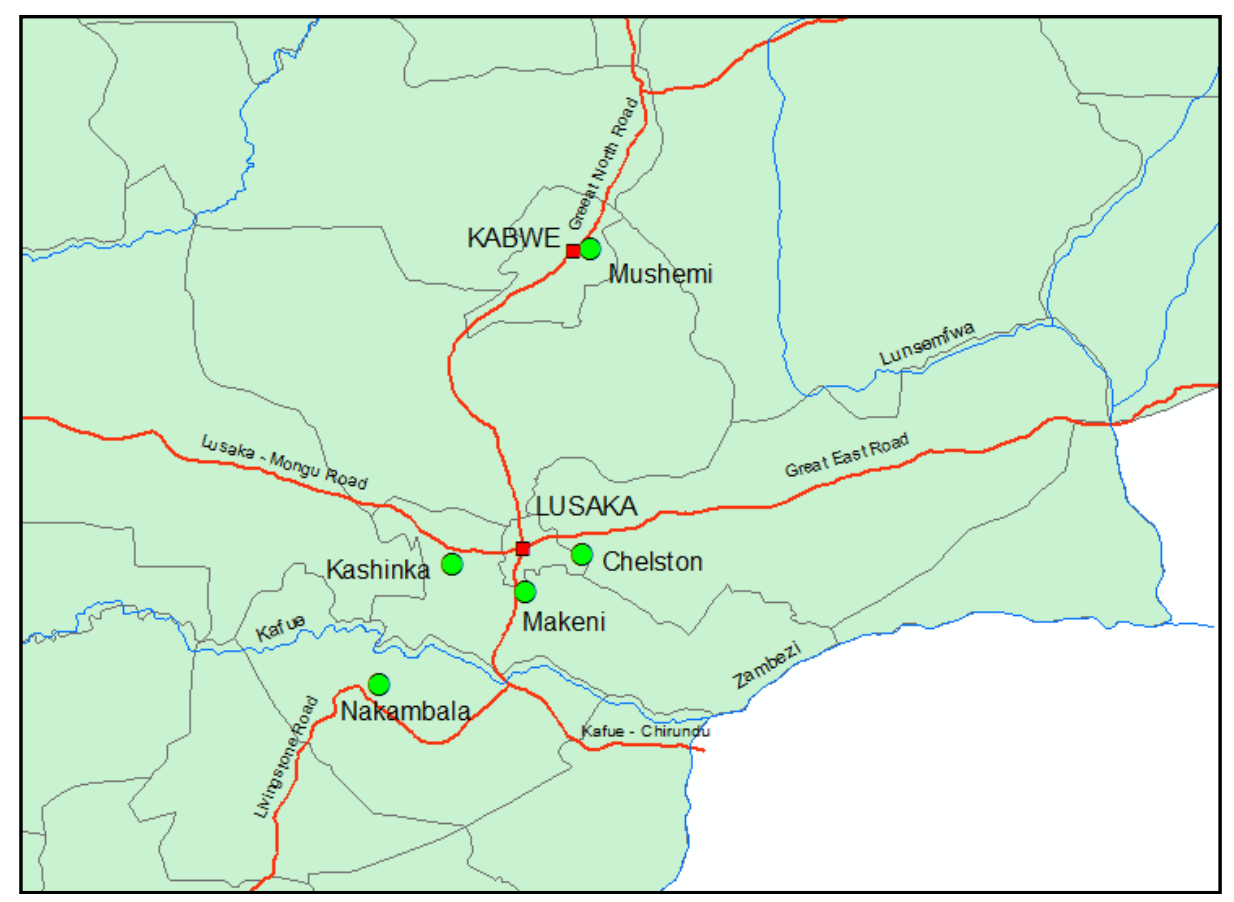

Figure 1. Location of selected benchmark soils used in the study.

same time the undisturbed soil samples were collected using standard core rings (diameter $=0.05 \mathrm{~m}$, height $=0.05 \mathrm{~m}$ ) for selected soil hydraulic characterization. Extra $100 \mathrm{~kg}$ of soil was collected from the five-soil series at a depth of $0-20 \mathrm{~cm}$ for use during laboratory column experiments.

Chicken manure samples were collected from the chicken farmhouse within the School of Agricultural Sciences at the University of Zambia. The samples were air-dried and sieved through a $2 \mathrm{~mm}$ sieve.

\subsubsection{Soil Chemical Analysis}

The soil $\mathrm{pH}$ for the five (5) selected Benchmark soils was determined using Water Proof Tester Model pH Meter by Hanna Instruments in $0.01 \mathrm{M}$ calcium chloride using soil to solution ratio of 1:2.5. Measurements of the EC were estimated from measurements of a saturated extract of 1:5 soil water extract. Organic matter content was determined by Walkley-Black Dichromate reduction method [14] [15]. Total $\mathrm{N}$ in the soils was determined using the micro-Kjeldahl method. Available Phosphorus (P) was determined by using the Bray 1 method 
[16] and measured using a JENWAY 6305 UV Spectrophotometer. The exchangeable bases which include potassium $(\mathrm{K})$, sodium $(\mathrm{Na})$, calcium $(\mathrm{Ca})$ and magnesium $(\mathrm{Mg})$ were extracted with a $1 \mathrm{~N}$ neutral $(\mathrm{pH} 7)$ ammonium acetate solution using a soil: solution volume ratio of 1:5. The $\mathrm{K}$ and $\mathrm{Na}$ in the extract were read using flame emission on the Atomic Absorption Spectrophotometer Perkin Elmer analyst 400 model. Calcium (Ca) and Magnesium (Mg) concentrations were also measured using the Atomic Absorption Spectrophotometer (AAS). The micronutrients in the soil were extracted using Diethylenetriamine Patraacetic Acid (DTPA) solution and determined on the Perkin Elmer analyst 400 model Atomic Absorption Spectrophotometer. Separate soil samples amended with different amounts of manure ( $0 \%, 2 \%, 4 \%$ and $6 \%)$ were also analyzed for organic matter using the Walkley and Black method [14].

\subsubsection{Soil Physical Analysis}

Soil water content at field capacity and soil bulk density was determined from undisturbed core samples collected from a depth of $0-20 \mathrm{~cm}$ by the core method [17]. The quantitative determination of the distribution of the particle sizes was done using the procedure of the Standardized Bouyoucos Hydrometer Method [18]. The USDA textural triangle was used to determine the textural class. Moisture content and bulk density were determined on separate soil samples after manure $(0 \%, 2 \%, 4 \%$ and $6 \%)$ application and were measured on a weight per weight $(\mathrm{w} / \mathrm{w})$ ratio.

\subsubsection{Chicken Manure Analysis}

Chicken manure samples were air dried, sieved through a 2-mm sieve and chemically analyzed. The chicken manure $\mathrm{pH}$ was determined in 1:5 chicken manure-water ratio. Organic matter content was determined by Walkley-Black Dichromate reduction method [14]. Total $\mathrm{N}$ in the manure was determined using the micro-Kjeldahl method [19]. Percentage (\%) of available P in chicken manure was measured by first complete combustion of the sample and digesting the ash with $1 \mathrm{M}$ Nitric Acid solution and finally determined using the Bray 1 method [16]. Percentage (\%) of $\mathrm{K}$ in chicken manure was measured by digesting the ashed sample with $1 \mathrm{M}$ Nitric Acid solution. The concentration of potassium (K) was determined using the Atomic Absorption Spectrometer. Ash content of chicken manure was determined through dry combustion in a muffle furnace. Moisture content in the chicken manure was determined on weight basis.

\subsection{Experimental Design and Treatments}

To assess the influence of chicken manure amendment on the thermal properties of selected Benchmark soils in Zambia, a soil column experiment was laid out in the laboratory at the School of Agricultural Sciences at the University of Zambia. The five soil types representing benchmark soils in Zambia used in the soil column were from Makeni (Lilayi Farm), Mazabuka (Syrenga Farm), Chalimbana 
(Liempe Farm), Kabwe (Research Station) and (Kashinka Farm) (Figure 1). The soil column experiment was laid out in a Randomized Complete Block Design, with four treatments from each benchmark soil in four replicates. The treatments for each soil type comprised of four levels of poultry manure (0.0, 2.0, 4.0 and 6.0\%) on dry weight basis. Soils were packed in PVC columns of 50 $\mathrm{cm}$ long and cross-sectional area of $292.6 \mathrm{~cm}^{3}$. Each column was lined with aluminum foil on their inner surface to prevent heat loss during the experiment. The columns were also covered with wire mesh and wire gauze at the base.

\subsection{Soil Thermal Models}

Soil temperature profiles were monitored at 10,20,30, 40 and $50 \mathrm{~cm}$ depth at 30 minutes' interval for 8 hours using digital thermal couples and ordinary thermometers installed at corresponding depths within the soil columns. The heat source was provided by 250 -Watt infrared bulbs which were mounted on the surface of the soil in each column.

The measured soil temperature profiles were used to calculate the thermal properties of soil which included volumetric heat capacity, thermal conductivity, thermal diffusivity, and Damping depth. Soil thermal property estimation was performed by using empirical relationships and the Usowicz's physical model of thermal conductivity [8]. The volumetric heat capacity $C_{V}\left(\right.$ in $\left.\mathrm{J} \cdot \mathrm{m}^{-3} \cdot \mathrm{K}^{-1}\right)$ was calculated using the empirical formulae proposed by de Vries [7]:

$$
C_{v}=\left(2.0 * x_{s}+2.51 * x_{o}+4.19 * x_{w}\right) * 10^{6}
$$

where $x_{s}, X_{o}$ and $x_{W}\left(\mathrm{~m}^{3} \cdot \mathrm{m}^{-3}\right)$ are the volumetric contributions of mineral and organic components and water, respectively.

Thermal conductivity $(\lambda)$, the quantity of heat transferred through a unit area of the conducting body in unit time under a temperature gradient [1] was calculated from the soil temperature profiles based on Fourier's law of heat conduction as follows:

$$
\lambda=\frac{q_{l}}{4 \pi}\left(\frac{z_{1}-z_{2}}{T_{1}-T_{2}}\right)
$$

where $q_{I}$ is the heat flux, and $T_{1}$ and $T_{2}$ is the soil temperature at soil depth $z_{1}$ and $Z_{2}$ respectively.

The thermal diffusivity $D_{h}\left(\mathrm{~m}^{2} \cdot \mathrm{s}^{-1}\right)$, speed of heat conduction during changes of temperature, is calculated from the ratio of thermal conductivity $(\lambda)$ and volumetric heat capacity $(C V)$

$$
D_{h}=\frac{\lambda}{C_{v}}
$$

Damping depth (d), depth at which the temperature amplitude equals the amplitude at the soil surface is related thermal diffusivity and the frequency of temperature fluctuation by: 


$$
d=\sqrt{\frac{2 * D_{h}}{\omega}}
$$

where $d$ is the damping depth (m), $D_{h}$ is the thermal diffusivity $\mathrm{m}^{2} \cdot \mathrm{T}^{-1}$ and $\omega$ is the frequency of temperature fluctuation $\left(\mathrm{S}^{-1}\right)[1]$.

The input data needed for the calculations above consists of the soil mineralogical composition, organic matter content, porosity, temperature, and water content profiles. Moreover, the statistical-physical model requires reference data on the thermal conductivity of quartz, other minerals, organic matter, water and air.

\subsection{Data Analysis}

To determine significant differences among the treatments for the measured and computed parameters, data were subjected to analysis of variance (ANOVA) using GenStat Statistical Software. The Least Significant difference test was used to separate the means. Differences were declared significant at $\mathrm{p}<0.05$.

\section{Results and Discussion}

\subsection{Results on Selected Chemical Properties of the 5 Benchmark Soils}

Data on selected chemical analysis on the thermal properties of selected Benchmark soils in Zambia are presented in Table 2. The data revealed that all the 5 Benchmark soils used in the study were slightly acidic. The electrical conductivity of all the soils was low and less than $2 \mu \mathrm{S} \cdot \mathrm{cm}^{-1}$, indicating that these soils were free of salinity hazard. Organic matter for all the soils was adequate while Makeni soil also had the highest content of organic matter of $4.35 \%$ and Mushemi soils had a value of less than $2 \%$. All the soils had enough total nitrogen and available phosphorus except in Mushemi soil where available phosphorus was quite high about $26.42 \mathrm{mg} / \mathrm{kg}$. Mushemi and Kashinka soils had low potassium while with Makeni, Chelston and Nakambala soils had enough potassium. Nakambala soil had 23.60, Makeni 3.23, Chelston soil 2.49 and Kashinka soil 2.21 $\mathrm{mg} / \mathrm{kg}$. Mushemi had $0.11 \mathrm{Cmol} / \mathrm{kg}$, Kashinka soil (0.13 Cmol/kg), Makeni $(0.22$ $\mathrm{Cmol} / \mathrm{kg})$, Chelston $(0.29 \mathrm{Cmol} / \mathrm{kg})$ and $0.27 \mathrm{Cmol} / \mathrm{kg}$ for Nakambala soils.

Table 2. Chemical properties of the 5 benchmark soils.

\begin{tabular}{cccccccc}
\hline Location & Soil Type & $\begin{array}{c}\mathrm{pH} \\
\mathrm{CaCl}_{2}\end{array}$ & $\begin{array}{c}\mathrm{EC} \\
\mathrm{uS} \cdot \mathrm{cm}^{-1}\end{array}$ & $\begin{array}{c}\mathrm{OM} \\
\%\end{array}$ & $\begin{array}{c}\text { Total N } \\
\%\end{array}$ & $\begin{array}{c}\mathbf{P} \\
\mathbf{m g} / \mathbf{K g}\end{array}$ & $\begin{array}{c}\mathrm{K} \\
\mathrm{Cmol} / \mathrm{kg}\end{array}$ \\
\hline $\begin{array}{c}\text { Makeni-Lilayi Farm } \\
\text { Chalimbana-Liyempe Farm }\end{array}$ & Makeni & 5.73 & 0.06 & 4.35 & 1.60 & 3.23 & 0.22 \\
$\begin{array}{c}\text { Mazabuka-Syrenga farm } \\
\text { Kabwe }\end{array}$ & Nakambala & 5.74 & 0.07 & 2.16 & 0.93 & 23.60 & 0.27 \\
$\begin{array}{c}\text { Kashima Farm-Mumbwa } \\
\text { Road }\end{array}$ & Mushemi & 5.25 & 0.02 & 1.36 & 0.70 & 26.42 & 0.11 \\
\hline & Kashinka & 5.63 & 0.02 & 3.17 & 1.20 & 2.21 & 0.13 \\
\hline
\end{tabular}

$\mathrm{pH}=$ Soil Reaction, EC = Electrical Conductivity, $\mathrm{OM}=$ Organic Matter, Available phosphorus, $\mathrm{K}=\mathrm{Ex}-$ changeable Potassium. 


\subsection{Results on Selected Physical Properties of the 5 Benchmark Soils}

Table 3 shows data on soil physical analysis. The data indicated that the bulk densities of the soils used in the study were within range. There were no significant differences observed in bulk density among the soils. Makeni soils had the lowest bulk density $\left(1.17 \mathrm{gm} \cdot \mathrm{cm}^{-3}\right)$, and Mushemi soils had the highest $(1.21$ $\mathrm{gm} \cdot \mathrm{cm}^{-3}$ ). The textures of the soils were classified and fell within sandy loam (SL), silt loam (SL) and loam (L). The percentage of sand in all the soils was more than the percentage of silt except for Mushemi soil which had more silt than sand. Makeni and Chelston series had 53.9\% sand, Nakambala and Kashinka had $48.5 \%$ and $44.5 \%$ while Mushemi had $33.2 \%$. The texture of the soil is important as it influences the thermal properties of the soil. The sandier the soil, the lower the heat capacity. Thermal conductivity increases with increase in moisture content.

\subsection{Results on Selected Chemical and Physical Properties of Chicken Manure}

Results on chemical and physical properties of chicken manure are presented in Table 4. Data indicates a soil reaction $(\mathrm{pH})$ of 6.75 and a high organic matter content $(48.8 \%)$, total nitrogen (48\%), available Phosphorus $(47.04 \%)$ and Potassium $63.30 \%$. It had a moisture content of about $1.77 \%$ of the dry matter and ash content of about $15 \%$.

\subsection{Thermal Properties of Selected Benchmark Soils}

\subsubsection{Heat Capacity}

Data on thermal properties of the five selected soil series are presented in Table 5.

Table 3. Selected physical properties of the 5 benchmark soils.

\begin{tabular}{ccccccc}
\hline Location & Soil Series & $\begin{array}{c}\rho \mathrm{b} \\
\mathrm{g} / \mathrm{cm}^{-3}\end{array}$ & $\begin{array}{c}\text { Sand } \\
(\%)\end{array}$ & $\begin{array}{c}\text { Silt } \\
(\%)\end{array}$ & $\begin{array}{c}\text { Clay } \\
(\%)\end{array}$ & $\begin{array}{c}\text { Texture } \\
\text { (USDA) }\end{array}$ \\
\hline $\begin{array}{c}\text { Makeni-Lilayi Farm } \\
\text { Chalimbana-Liyempe Farm }\end{array}$ & Makeni & 1.38 & 53.87 & 28.80 & 17.33 & Sandy loam \\
Mazabuka-Syrenga farm & Nakambala & 1.63 & 48.53 & 38.80 & 12.67 & Loam \\
Kabwe & Mushemi & 1.46 & 33.20 & 56.80 & 10.00 & Silt loam \\
Kashima Farm-Mumbwa Road & Kashinka & 1.69 & 44.53 & 38.13 & 17.33 & Loam \\
\hline
\end{tabular}

$\rho b=$ Bulk Density

Table 4. Physical and chemical properties of chicken manure.

\begin{tabular}{cccccccc}
\hline & $\begin{array}{c}\mathrm{pH} \\
\left(\mathrm{H}_{2} \mathrm{O}\right)\end{array}$ & $\begin{array}{c}\mathbf{0 . M} \\
(\%)\end{array}$ & $\begin{array}{c}\mathrm{N} \\
(\%)\end{array}$ & $\begin{array}{c}\mathrm{P} \\
(\%)\end{array}$ & $\begin{array}{c}\mathrm{K} \\
(5)\end{array}$ & $\begin{array}{c}\text { Ash } \\
\text { Content (\%) }\end{array}$ & $\begin{array}{c}\text { Moisture } \\
\text { Content (\%) }\end{array}$ \\
\hline Chicken Manure & 6.75 & 48.8 & 13.39 & 47.04 & 63.30 & 15.0 & 1.77 \\
\hline
\end{tabular}

$\mathrm{pH}=$ Soil reaction, $\mathrm{OM}=$ organic matter, $\mathrm{N}=$ Total nitrogen, $\mathrm{P}=$ Available phosphorus, $\mathrm{K}=$ Exchangeable Potassium. 
Table 5. Thermal properties of selected soil series of benchmark soils in Zambia.

\begin{tabular}{cccccc}
\hline Soil Type & $\begin{array}{c}\rho_{b} \\
\left(\mathrm{~g} / \mathrm{cm}^{3}\right)\end{array}$ & $\begin{array}{c}C_{\mathrm{v}} \\
\left(\mathrm{MJ} \cdot \mathrm{m}^{-3} \cdot \mathrm{C}^{-1}\right)\end{array}$ & $\begin{array}{c}\lambda \\
\left(\mathrm{W} \cdot \mathrm{m}^{-1} \cdot \mathrm{C}^{-1}\right)\end{array}$ & $\begin{array}{c}D \\
\left(\mathrm{~m}^{2} \mathrm{~s}\right)\end{array}$ & $\begin{array}{c}\boldsymbol{d} \\
(\mathrm{cm})\end{array}$ \\
\hline Chelstone & $1.21^{\mathrm{ab}}$ & $4.69^{\mathrm{a}}$ & $0.23^{\mathrm{a}}$ & $0.053^{\mathrm{bc}}$ & $37.6^{\mathrm{bc}}$ \\
Kashinka & $1.17^{\mathrm{a}}$ & $6.31^{\mathrm{b}}$ & $0.25^{\mathrm{a}}$ & $0.044^{\mathrm{ab}}$ & $34.0^{\mathrm{b}}$ \\
Makeni & $1.17^{\mathrm{a}}$ & $8.62^{\mathrm{c}}$ & $0.24^{\mathrm{a}}$ & $0.028^{\mathrm{a}}$ & $27.4^{\mathrm{a}}$ \\
Mushemi & $1.22^{\mathrm{b}}$ & $3.87^{\mathrm{a}}$ & $0.21^{\mathrm{a}}$ & $0.069^{\mathrm{c}}$ & $41.8^{\mathrm{c}}$ \\
Nakambala & $1.21^{\mathrm{ab}}$ & $4.39^{\mathrm{a}}$ & $0.26^{\mathrm{a}}$ & $0.062^{\mathrm{c}}$ & $40.5^{\mathrm{c}}$ \\
Mean & $1.20^{\mathrm{ns}}$ & $5.58^{* * *}$ & $0.24^{\mathrm{ns}}$ & $0.051^{* * *}$ & $36.2^{* * *}$ \\
CV (\%) & 5.6 & 33.1 & 21.8 & 45.1 & 20.9 \\
LSD & 0.047 & 1.300 & 0.036 & 0.016 & 5.3 \\
P-value & 0.07 & $<0.001$ & 0.082 & $<0.001$ & $<0.001$ \\
\hline
\end{tabular}

${ }^{* * *}=$ very highly significant, $\mathrm{ns}=$ non-significant, values with the same letter are not significantly different at $\mathrm{p}>0.05, \rho_{b}=$ bulk density, $C_{V}=$ Volumetric Heat Capacity, $\lambda=$ Thermal Conductivity, $D_{h}=$ Thermal Diffusivity, $d=$ Damping Depth.

Although all the soils had high values of volumetric heat capacity, they were significant differences $(\mathrm{p}<0.05)$ observed among the soil series. Mushemi soils had the lowest value $\left(3.87 \mathrm{MJ} \cdot \mathrm{m}^{-3} \cdot \mathrm{C}^{-1}\right)$, and Makeni soils had the highest value $\left(8.62 \mathrm{MJ} \cdot \mathrm{m}^{-3} \cdot \mathrm{C}^{-1}\right)$. The high $C_{V}$ may be attributed to the initial organic matter content which was more than $2 \%$ in all the soils except Mushemi soil. Literature [20] states that if the organic content is high, volumetric heat capacity $\left(C_{v}\right)$ will be high. Since organic content in all the soils was more than $2 \%$, then the $C_{V}$ was expected to be high.

\subsubsection{Thermal Conductivity}

There were no significant differences observed in thermal conductivity for the five (5) soil series. Thermal conductivity varied from lowest $\left(0.21 \mathrm{~W} \cdot \mathrm{m}^{-10} \cdot \mathrm{C}^{-1}\right)$ for Mushemi soils and highest $\left(0.26 \mathrm{~W} \cdot \mathrm{m}^{-10} \cdot \mathrm{C}^{-1}\right)$ for Nakambala soils. The average value for the soils was $0.24 \mathrm{~W} \cdot \mathrm{m}^{-10} \cdot \mathrm{C}^{-1}$. Thermal Conductivity is important for the transmission of heat in the soil [21] and since there were no significant differences in thermal Conductivity, heat transmission was the same among the five (5) soil series.

\subsubsection{Thermal Diffusivity}

Significant differences $(\mathrm{p}<0.05)$ were observed regarding thermal diffusivity $\left(D_{h}\right)$ among the soils. The mean value was $0.051 \mathrm{~m}^{2} \mathrm{~s}$. Makeni soils had the lowest thermal diffusivity $\left(0.028 \mathrm{~m}^{2} \mathrm{~s}\right)$ while Mushemi Soils had the highest value (0.069 $\mathrm{m}^{2} \mathrm{~s}$ ). Although all the soils had low thermal diffusivity, significant differences ( $\mathrm{p}$ $<0.05)$ were observed between Makeni and Chelstone Soils, Makeni and Nakambala Soils and Makeni and Mushemi Soils. Thermal diffusivity affects the distribution of heat and soil heat flux density [22]. In this case, it shows that there were differences in the way heat is conducted among the soils. 


\subsubsection{Damping Depth}

The results on damping depth showed significant differences $(\mathrm{p}<0.05)$ among the soil series (Table 5). Damping depth varied from 27.4 to $41.8 \mathrm{~cm}$ with the mean damping depth of $36.2 \mathrm{~cm}$. There were significant differences $(\mathrm{p}<0.05)$ observed among the soil series. Makeni series had the lowest damping depth $(27.4 \mathrm{~cm})$, while Mushemi and Nakambala series had the highest value ( $>40.0$ $\mathrm{cm}$ ), however falling within $50 \mathrm{~cm}$ of soil depth important root-zone for most annual crops. Damping depth, a constant characterizing the decrease in amplitude with an increase in distance from the soil surface show how deep the heat source at the surface influences depth of heat change or temperature change [23]. It is important for determining temperature status and selecting necessary land management to provide optimum temperature.

\subsection{Effect of Chicken Manure on Thermal Properties of Soils}

For all the five (5) soil series, chicken manure application significantly affected the volumetric heat capacity of the soil. The addition of chicken manure influences the volumetric heat capacity of a given soil. As stated by [22] heat capacities of different solid constituents vary at different proportions of added organic materials. The data revealed that soil without chicken manure had the lowest while the amended soil at $6 \%$ treatment had the highest Volumetric Heat Capacity $\left(C_{v}\right)$. As the amount of chicken manure increased, the heat capacity of the soils also increased, and the $C_{V}$ at all levels of chicken manure was significantly different $(\mathrm{p}<0.05)$. Volumetric Heat Capacity $\left(C_{v}\right)$ is used for storage of heat in the soil. Therefore, soils with high chicken manure will have high heat capacity because manure does not easily lose or gain heat and hence increases the heat capacity and more heat is stored.

The result of the effect of chicken manure on thermal conductivity is presented in Table 6 . Thermal conductivity varied from $0.210\left(\mathrm{~W} \cdot \mathrm{m}^{-1} \cdot \mathrm{C}^{-1}\right)$ for $6 \%$,

Table 6. Effect of chicken manure on thermal properties of soils.

\begin{tabular}{cccccc}
\hline $\begin{array}{c}\text { Manure } \\
\text { Rate }\end{array}$ & $\begin{array}{c}\rho_{b} \\
\left(\mathrm{gm} / \mathrm{cm}^{3}\right)\end{array}$ & $\begin{array}{c}C_{V} \\
\left(\mathrm{MJ} \cdot \mathrm{m}^{-3} \cdot \mathrm{C}^{-1}\right)\end{array}$ & $\begin{array}{c}\lambda \\
\left(\mathrm{W} \cdot \mathrm{m}^{-10} \cdot \mathrm{C}^{-1}\right)\end{array}$ & $\begin{array}{c}D_{h} \\
\left(\mathrm{~m}^{2} \mathrm{~s}\right)\end{array}$ & $\begin{array}{c}d \\
(\mathrm{~cm})\end{array}$ \\
\hline 0 & $1.27^{\mathrm{a}}$ & $4.15^{\mathrm{b}}$ & $0.254^{\mathrm{a}}$ & $0.073^{\mathrm{a}}$ & $43.5^{\mathrm{a}}$ \\
2 & $1.23^{\mathrm{b}}$ & $5.33^{\mathrm{b}}$ & $0.262^{\mathrm{a}}$ & $0.057^{\mathrm{b}}$ & $38.6^{\mathrm{b}}$ \\
4 & $1.17^{\mathrm{c}}$ & $5.47^{\mathrm{b}}$ & $0.216^{\mathrm{b}}$ & $0.043^{\mathrm{b}}$ & $34.0^{\mathrm{b}}$ \\
6 & $1.11^{\mathrm{d}}$ & $7.36^{\mathrm{a}}$ & $0.210^{\mathrm{b}}$ & $0.032^{\mathrm{c}}$ & $29.0^{\mathrm{c}}$ \\
Mean & $1.20^{* * *}$ & $5.58^{* * *}$ & $0.236^{* * *}$ & $0.051^{* * *}$ & $36.2^{* * *}$ \\
CV\% & 2.5 & 40.8 & 20.5 & 43.3 & 20.4 \\
LSD & 0.02 & 1.435 & 0.030 & 0.014 & 0.7 \\
p-value & $<0.001$ & $<0.001$ & $<0.001$ & $<0.001$ & $<0.001$ \\
\hline
\end{tabular}

${ }^{* * *}=$ very highly significant, means with the same letter were not significantly different at $\mathrm{p}<0.05 \rho_{b}=$ bulk density, $C_{V}=$ Volumetric Heat Capacity, $K=$ Thermal Conductivity, $D=$ Thermal Diffusivity, $d=$ Damping Depth. 
to $0.25\left(\mathrm{~W} \cdot \mathrm{m}^{-1} \cdot \mathrm{C}^{-1}\right)$ under $0 \%$ chicken manure with mean value of $0.24\left(\mathrm{~W} \cdot \mathrm{m}^{-1} \cdot \mathrm{C}^{-1}\right)$. There were significant differences $(\mathrm{p}<0.05)$ in thermal conductivity among the treatments. Increased manure application reduced the thermal conductivity of the soils. The results showed that addition of chicken manure to the soil decreased the thermal conductivity of the soil. Similar trends were observed Thermal conductivity and diffusivity of fallow soil decreased with biochar addition rate.

Incorporation of the chicken manure into the soil led to reduced soil bulk density of the soil from $1.27 \mathrm{~g} / \mathrm{cm}^{3}$ to $1.11 \mathrm{~g} / \mathrm{cm}^{3}$. Similarly application of chicken manure significantly reduced thermal diffusivity of the soils. There were significant differences $(\mathrm{p}<0.05)$ in thermal diffusivity for soil under $6 \%$ chicken manure $\left(D_{h}=0.032 \mathrm{~m}^{2} \mathrm{~s}\right)$ and $0 \%$ chicken manure $\left(D_{h}=0.073 \mathrm{~m}^{2} \mathrm{~s}\right)$ as well as for $4 \%$ chicken manure $\left(D_{h}=0.043 \mathrm{~m}^{2} \mathrm{~s}\right)$ and $0 \%$ rates with $0.073 \mathrm{~m}^{2} \mathrm{~s}$.

The effect of chicken manure on damping depth showed that the range of damping depth among the soil was from $43.5 \%$ to $0 \%$ to $29.0 \mathrm{~cm}$ for $6 \%$ chicken manure application rate. Chicken manure application for $4 \%$ with $34.0 \mathrm{~cm}$ and $6 \%$ rate of $29.0 \mathrm{~cm}$ significantly affected the damping depth of the soil. As the chicken manure application increased, the damping depth decreased. From the study, the data provides an observed interpretation of the influence of chicken manure as a soil amendment on the soil's thermal properties for the five selected Benchmark soils.

According Edem [24] organic manure inclusion at any rate significantly dampen heat transfer in the soil.

\section{Conclusion}

The study was undertaken to assess the influence of chicken manure amendment on the thermal properties of 5 selected benchmark soils of Zambia. The studied soil types showed differences in some of their thermal properties. The study revealed that there were significant differences $(p<0.05)$ in volumetric heat capacity, thermal diffusivity, and damping depth while thermal conductivity was not significantly different among the soils. This implied that these soil types would react differently when exposed to heat sources and sink. Soil organic amendment with chicken manure significantly affected thermal properties of the studied soils. Thermal conductivity $(K)$ and Thermal Diffusivity $\left(D_{h}\right)$ decreased while Volumetric Heat Capacity $\left(C_{V}\right)$ increased. These affect the retention and transmission of heat in the soil. Since chicken manure has high amounts of moisture, this indicates that soils with chicken manure absorb and retain moisture with chicken manure amendment. Therefore, the use of chicken manure is a potential source of moisture, and as such, it is recommended that farmers should know how to effectively manipulate organic amendments to ensure that moisture is maintained even during dry spells. This is important because it helps farmers manage soil under the influence of climate change. 


\section{Conflicts of Interest}

The authors declare no conflicts of interest regarding the publication of this paper.

\section{References}

[1] Hillel, D. (2004) Introduction to Environmental Soil Physics.

[2] Tanaka, K., Tamagawa, I., Ishikawa, H., Ma, Y. and Hu, Z. (2003) Surface Energy Budget and Closure of the Eastern Tibetan Plateau during the GAME-Tibet IOP 1998. Journal of Hydrology, 283, 169-183. https://doi.org/10.1016/S0022-1694(03)00243-9

[3] Su, Z. (2002) The Surface Energy Balance System (SEBS) for Estimation of Turbulent Heat Fluxes. Hydrology and Earth System Sciences, 6, 85-100. https://doi.org/10.5194/hess-6-85-2002

[4] Luo, Y., Arnold, J., Liu, S., Wang, X. and Chen, X. (2013) Inclusion of Glacier Processes for Distributed Hydrological Modeling at Basin Scale with Application to a Watershed in Tianshan Mountains, Northwest China. Journal of Hydrology, 477, 72-85. https://doi.org/10.1016/j.jhydrol.2012.11.005

[5] Wagner-Riddle, C. and Thurtell, G.W. (1998) Nitrous Oxide Emissions from Agricultural Fields during Winter and Spring Thaw as Affected by Management Practices. Nutrient Cycling in Agroecosystems, 52, 151-163.

https://doi.org/10.1023/A:1009788411566

[6] De Varies, D.E. (1963) Thermal Properties of Soils. In: van Wijk, W.R., Ed., Physics of the Plant Environment, North-Holland Publishing Co., Amsterdam, 210-235.

[7] Bradford, K.J. (1995) Water Relations in Seed Germination. Marcel Dekker, Inc., New York.

[8] Usowicz, B. (1992) Statistical-Physical Model of Thermal Conductivity in Soil. Polish Journal of Soil Science, 25, 25-34.

[9] Aliyu, L. (2000) Effect of Organic and Mineral Fertilizers on Growth, Yield and Composition of Pepper (Capsicum annuum L.). Biological Agriculture and Horticulture, 18, 29-36. https://doi.org/10.1080/01448765.2000.9754862

[10] Lal, R. (2016) Soil Health and Carbon Management. Food and Energy Security, 5, 212-222. https://doi.org/10.1002/fes3.96

[11] Bartelli, L.J. (1979) Technical Classification System for Soil Survey Interpretation. Advances in Agronomy, 30, 247-289. https://doi.org/10.1016/S0065-2113(08)60708-7

[12] Miller, B.A. and Schaetzl, R.J. (2016) History of Soil Geography in the Context of Scale. Geoderma, 264, 284-300. https://doi.org/10.1016/j.geoderma.2015.08.041

[13] Lungu, V.R. and Chinene, O.I. (1993) Cropping and Soil Management Systems and their Effect on Soil Productivity in Zambia. Oslo, Norway.

[14] Walkley, A. and Black, I.A. (1934) An Examination of Degtjareff Method for Determining Soil Organic Matter and a Proposed Modification of the Chromic Acid Titration Method. Soil Science, 37, 29-37. https://doi.org/10.1097/00010694-193401000-00003

[15] Walkley, A. (1947) A Critical Examination of a Rapid Method for Determining Organic Carbon in Soils: Effect of Variations in Digestion Conditions and Inorganic Soil Constituents. Soil Science, 63, 251-264. https://doi.org/10.1097/00010694-194704000-00001 
[16] Bray, L.T. and Kurtz, R.H. (1945) Determination of Total Organic and Available Forms of Phosphorus in Soils. Soil Science, 59, 39-45. https://doi.org/10.1097/00010694-194501000-00006

[17] Bashour, I.I. and Sayegh, A.H. (2007) Methods of Analysis for Soils of Arid and Semi-Arid Regions. FAO, Beirut.

[18] Bouyoucos, G. (1962) Hydrometer Method Improved for Making Particle Size Analysis of Soil. Agronomy Journal, 54, 464-465. https://doi.org/10.2134/agronj1962.00021962005400050028x

[19] Al Steyermark, R.R.K., McGee, B.E. and Bass, E.A. (1958) Micro-Kjeldahl Method for Nitrogen in Certain Organic Compounds Containing Nitrogen-Nitrogen and Nitrogen-Oxygen Linkages. Analytical Chemistry, 30, 1561-1563. https://doi.org/10.1021/ac60141a036

[20] Yadav, M.R. and Saxena, G.S. (1973) Effect of Compaction and Moisture Content on Specific Heat and Thermal Capacity of Soils. Indian Society of Soil Science, 21, 129-132.

[21] Johansen, O. (1975) Thermal Conductivity of Soils. Norwagian University of Science and Technology, Trondheim.

[22] Kersten, M. (1952) Thermal Properties of Soils.

[23] Ghuman, B.S. and Lal, R. (1985) Thermal Conductivity, Thermal Diffusivity, and Thermal Capacity of Some Nigerian Soils. Soil Science, 139, 74-80. https://doi.org/10.1097/00010694-198501000-00011

[24] Edem, D. (2015) Effect of Animal Droppings on Thermal Properties of Dispersed Porous System. Trends in Soil Fertility and Plant Nutrition, 3, 13-18. 